\title{
Acquired Cystic Disease-Associated Renal Cell Carcinoma
}

National Cancer Institute

\section{Source}

National Cancer Institute. Acquired Cystic Disease-Associated Renal Cell Carcinoma. NCI Thesaurus. Code C157718.

The most common renal cell carcinoma that develops in patients with end-stage renal disease and acquired cystic disease. 